\title{
The Changing Portrayal of Epilepsy in the Theatre
}

Michael White ${ }^{1}$ and Dominic Simpson ${ }^{2}$

${ }^{1}$ Translational and Clinical Research Institute, Newcastle University, Newcastle upon Tyne, NE2

4HH, UK. Contact email: Michael.white2@ncl.ac.uk. ORCID 0000-0002-3465-0592. To whom correspondence should be addressed.

${ }^{2}$ Faculty of Medical Sciences, Newcastle University, Newcastle upon Tyne, NE2 4HH, UK.

Keywords: Epilepsy, Theatre, Neurology, Cultural History, Drama, Engagement, Medical Communication

\begin{abstract}
:
The theatre has a tremendous ability to influence public discourse and shape societal opinions. And medical conditions can provide writers with a rich scope for plot development and characters with challenges to overcome. In particular, the neurological condition epilepsy has many possibilities with historical beliefs that people were possessed by gods and devils and the sudden, disabling seizures characteristic of the condition. But used unsympathetically, it can promote misunderstanding within audiences, resulting in discrimination for people with the condition.

This review looks back at how epilepsy has been portrayed throughout history. How the Greeks portrayed epilepsy as a punishment from the gods. Then later, how Shakespeare utilised epilepsy to suggest characters as uncontrollable. However, we finish on a message of hope as modern writers look to collaboration to ensure accurate and honest portrayals of epilepsy, improving public understanding and removing many of the stigmas that have dogged the condition.
\end{abstract}




\section{Introduction}

At its most simple, theatre is a form of entertainment but one that also informs, educates and shapes public opinion. And it doesn't matter whether a play is written a long time ago or more recently, plays have the potential to resonate over generations. The plays of William Shakespeare continue to be studied and performed around the world despite being over 400 years old. In the hands of a skilled playwright and director, theatre can increase public understanding and provide opportunities to empathise with different groups of people such as those with disabilities.

Health conditions have always appeared in theatre, being used as a means of plot progression or to define a character, often as a sign of weakness (Trimble and Hesdorffer 2016, 242). But these portrayals are not always accurate and their use in drama has the potential to distort and sensationalise public understanding of disability (Kerson, Kerson, and Kerson 2000, 108). Therefore many theatre companies have taken to collaborating with universities and other organisations to accurately explore health issues. These shows use storytelling to explain the often complex science and personal impact of conditions. This paper looks at the portrayal of one particular disability in the theatre and how this new generation of theatre groups are rejecting stereotypes to lead the way with honest, engaging portrayals of epilepsy. Helping to change some of the negative attitudes towards the condition that still exist (Holmes, Bourke, and Plumpton 2018, 15

\section{Ancient Times}

Reports of epileptic seizures have been recorded in papers dating back to around $2000 \mathrm{BC}$ (Magiorkinis, Sidiropoulou, and Diamantis 2010, 103). But, the physiological basis of epilepsy has not always been known. As a result seizures were often attributed to people being possessed by some sort of spirit or god. These spirits could be seen as being both good and bad. This was the case in Ancient Greece where the word epilepsy originates from, meaning "to seize, possess, or afflict." (Magiorkinis, Sidiropoulou, and Diamantis 2010, 104). Modern records show one Greek playwright in particular included characters who appear to succumb to symptoms that sound like seizures. This playwright was Euripides, whose work includes the plays Iphigenia among the Taureans and Heracles.

In Iphigenia among the Taureans, a young foreigner called Orestes is observed by locals suffering from a number of symptoms that are could be synonymous with epilepsy.

Meanwhile one of the two strangers left the cliff and stood shaking his head this way and that. He groaned aloud, his hands trembled... (Euripides 1999, 179).

At the end of the event, Orestes is described as having 'fell down, foam dripping from his chin' before 'now in his senses, leapt up from his fall...' (Euripides 1999, 181). A description of symptoms that would match that of a tonic-clonic seizure. The story is that Orestes has been afflicted by the Erinyes, gods of vengeance, for killing his mother in order to avenge his father's death. These seizures are a temporary, intermittent affliction, as Orestes is unaffected throughout the rest of the play. But the description ties in with an epileptic seizure. Orestes has unusual head movements, muscle contractions, hallucinations and blackouts. Following the seizure he regains awareness of himself and his surroundings.

The story of Orestes is also incorporated into a trilogy by Aeschylus called the Oresteia which follows a curse that runs in Orestes' family. The madness afflicted on Orestes by the Erinyes is described by the chorus in the third play called Eumenides. 
He is too mad to know that he falls;

Pollution floats around him, darkening his vision. (Aeschylus, 2007, 107).

While these lines can be interpreted as a lack of self-awareness for Orestes, there are also similarities to a generalised seizure. This is where someone will lose consciousness and afterwards may be unaware of having had a seizure. It is reasonable to presume that Aeschylus, like Euripides, is making a conscious decision to link Orestes with epilepsy.

Similarly in Heracles, another play by Euripides, the goddess Madness is sent by the goddess Hera to attack the titular character. During the play he suffers from what comes across as a seizure.

He looked lightning-struck. Eyes white, veins throbbing, his beard spit-drooled...

(Euripides 1997, 135)

Heracles then goes on to attack and kill members of his own family believing them to be his enemies. This attack is only temporary and when Heracles regains consciousness he states:

I'm alive. Clear eyes. Breathing. I see the sky, Mother Earth, The arrows of the sun.

Inside, I'm drowning, My mind choking, Fire in the lungs, Flames, roaring... Tell

me what's happening. I don't understand. (Euripides 1997, 141)

People with epilepsy will generally lose awareness during a seizure and are unaware of the loss of time. During certain types of seizure, the body undergoes extreme physical exertions leaving people physically exhausted. Similarly in the immediate phase after a seizure, as the brain slowly starts to recover, people can become anxious and confused, failing to recognise familiar faces. As a warrior, while in such a state, it may be of no surprise that Heracles lashes out in extreme violence only to be unaware of his actions once fully recovered. The Greeks considered epilepsy to be a condition delivered by the gods as punishment (Magiorkinis et al 2014, 1). Heracles' seizures are a punishment for being the illegitimate son of Zeus, king of the gods. During their episodes, both characters are portrayed as mad, but there is enough to suggest that through the choice of text used, Euripides had epilepsy in mind as he wrote.

Euripides' work was written just before a major shift in the understanding of epilepsy occurred, moving away from spiritual origins. On the Sacred Disease, part of the Hippocratic Corpus, states 'This disease is in my opinion no more divine than any other; it has the same nature as other diseases, and the cause that gives rise to individual diseases' (Hippocrates, n.d.). Despite this understanding of the physical nature of epilepsy amongst physicians, it would have been difficult for this knowledge to have spread through the general population away from the spiritual beliefs.

\section{Shakespeare and Epilepsy}

Theatre records are very quiet after the Greeks and Romans until around the time of the Tudors. It is unlikely that no theatre was going on during this time, instead it may have been on a smaller scale. Plays and stories were also passed down by word of mouth as opposed to being documented on paper. The ability to document and produce copies of scripts would have been a painstaking process until the arrival of the printing press in the late 1400s. However, by the late 1500s, the literary records become filled with an explosion of plays, in particular from the Elizabethan playwright William Shakespeare and a number of his plays contain references to epilepsy. Indeed, epilepsy is used as a character trait for two titular characters, Julius Caesar and Othello. Julius Caesar is a historical play written about characters and events that actually occurred, but that have been embellished for the stage. It is believed that the real Julius Caesar suffered from seizures of some sort, generally believed 
to be epilepsy. Othello, however, is an act of fiction inspired in part by a story called 'A Moorish Captain' (D Kindersley Ltd 2015, 244).

The plot of Julius Caesar follows the assassination of the titular Roman Emperor by members of the Roman Senate and the power struggle that takes place afterwards. Towards the start of the play an incident occurs in Rome's marketplace where Caesar has gone to greet the people of Rome after returning home victorious from war against his rival Pompey.

CASCA: He fell down in the market-place, and foamed at the mouth, and was speechless.

BRUTUS: 'T is very like: he hath the falling sickness (Shakespeare, n.d. 17)

What is described is likely to be tonic-clonic seizure, with the collapsing on the ground and shaking. Shakespeare is making it very clear to the audience as to what has caused the fall by mentioning the falling sickness, an old term for epilepsy. He then goes on to use this very public incident to portray contrasting reactions to Caesar. To Casius and his enemies in the senate, the seizure suggests weakness, something that is unbecoming for the leader of Rome.

CASIUS: 'T is true, this god did shake; His coward lips did from their colour fly, And that same eye whose bend doth awe the world did lose his lustre; (Shakespeare, n.d. 13)

To them it becomes a justification that he is unfit to be Emperor of Rome. However, in contrast, it allows Caesar to establish a connection with the people of Rome that strengthens his position.

CASCA: When he came to himself again, he said, if he had done or said anything amiss, he desired their worships to think it was his infirmity. Three or four wenches where I stood cried 'Alas, good soul!' and forgave him with all their hearts;

(Shakespeare, n.d. 18)

For the crowd, the seizure allows them to gain a sense of connection to Caesar. He is shown to have a human side, a weakness that people can relate to. This sudden relatability increases Caesar's support from the people of Rome. This galvanises the Senate to take matters into their own hands before Caesar's power grows too large. Like the Greeks, the Romans considered epilepsy to be linked to the gods. Indeed the condition was often known as the "sacred disease." This supposed connection to the Gods meant that it wasn't always seen as a negative and may have even been played on by individuals (Galassi and Ashrafian 2015, 1521). After all, anybody with any sort of perceived connection with the Gods, should be taken note of.

The story of Othello revolves around the attempt of a soldier, Iago, to destroy the life of his general, Othello. Othello, despite being a foreigner, has risen to the rank of General in the Venetian army. During the play, Shakespeare includes the stage direction that Othello 'falls in a trance' which is further supported when Iago tells an entering character:

IAGO: My lord is fall'n into an epilepsy; This is his second fit; he had one yesterday.

(Shakespeare, n.d. 92)

This is the first time that epilepsy is referred to in the play, with no suggestion that a previous seizure had occurred over the period the play takes place. This makes us question what Iago is saying, but that Othello collapses at this point is without question. When Othello comes out of the trance, Iago tells him: 
Whilst you were here o'erwhelmed with your grief, a passion most unsuiting such a man, Cassio came hither; I shifted him away, and laid good 'scuse upon your ecstacy (Shakespeare, n.d. 93)

In this quote explaining what has happened to him, Iago pointedly fails to mention epilepsy to Othello. It is possible that Iago is not wanting to embarrass his General but his previous scheming against Othello suggests there is more to it than that. Epilepsy was a much feared condition in Shakespeare's times and so having Iago informing Cassio that Othello had epilepsy would have lowered Othello's standing. It is also likely that Cassio, who at this point in the play is out of favour with Othello, will mention it to other colleagues in the army. Iago's claim that he provided a good excuse is just one more lie that Iago tells during the play.

But the fact that Othello does collapse, in a likely seizure, also further marks Othello out as being different from the other characters. From the start Othello is an outsider, a Moor, in charge of the Venetian army in a war against a Turkish invasion. The Moors were Muslim inhabitants from around the Iberian peninsula. He is married to a young Venetian but the marriage has been renounced by her father because he is a foreigner. He is then manipulated by Iago to believe that his wife is having an affair. All of these factors add up to place Othello under great stress, required to justify his position. And for people with epilepsy, increased levels of stress can often be a trigger for seizures.

Epileptic seizures are an electrical surge within the brain that means the brain is unable to function properly. Although it is also possible for people to have non-epileptic seizures which appear similar to epileptic seizures but are not neurological in nature. Instead they are psychogenic. Without clinical testing, it can often be difficult for the untrained eye to distinguish between the two. Therefore it is possible that the seizure or trance Othello falls into is a coping mechanism by the brain and so not epilepsy. However, this is a scientific divergence and unlikely to cross the minds of an audience. For many audiences, even today, any type of seizure means epilepsy.

Afflicting both men with epilepsy, escalates the tragedy of the characters to audiences, linking them to the idea of loss of self-control (Cazan 2014, 504). During the Elizabethan period, physical disabilities were often seen as external expressions of internal impairments. Therefore the physical manifestation of the seizures would have reflected on their characters. Both Julius Caesar and Othello are powerful men, in charge of large armies. That they could be in control of such strength and yet not always be in control of themselves means they are portrayed as threatening. In regards to Othello, without epilepsy he is just a suspicious and angry man. The removal of control through epilepsy escalates the ultimate tragic ending of the play.

The word 'epileptic' is also used by Shakespeare in the play King Lear when the Earl of Kent insults the servant Oswald during a confrontation saying "A plague upon your epileptic visage" (Shakespeare, n.d. 50). The analogy has been suggested to refer to a contorted, unnatural looking face with Oswald attempting to smile at Kent while being filled with terror (Cazan 2014, 512). It portrays an image of his muscles contracting, twitching uncontrollably as may occur during a seizure. However the phrase has been interpreted differently, with suggestions that it relates to syphilitic sores on Oswald's face (Betts and Betts 1998, 408). This interpretation has an inherent weakness in it. Describing Oswald's appearance as epileptic highlights the psychological conflict within him. Noting that Oswald may have suffered from syphilis adds nothing to the confrontation between the two men. Therefore the link to the contracted muscles of a seizure is the better supported argument.

\section{$20^{\text {th }}$ Century Plays}


The idea of fear and misunderstanding in epilepsy are continued in a play from the 1930s. Originally produced in the UK as To What Red Hell and later in America as At the Stroke of Eight, the play follows protagonist Harold Fairfield who strangles a young woman during a seizure. He is excused culpability for the death because of the seizure but ultimately takes his own life in the fear that it might happen again. Written by Percy Robinson, To What Red Hell prays on similar fears to stories such as Dr Jekyll and Mr Hyde by Robert Louis Stevenson. That is the possibility that a person may be transformed momentarily out of their control into something more sinister. While there are rare examples of violent behaviours being associated with temporal or frontal lobe seizures, these are rarely controlled or intentionally directed (Marsh and Krauss 2000, 161).

Historically, advances in the understanding of epilepsy during the $18^{\text {th }}$ and $19^{\text {th }}$ Centuries had resulted in people with epilepsy being treated as medical patients as opposed to being possessed or insane (Magiorkinis et al. 2014, 1). However, public opinion was slower to change. As late as the 1920s, novelist Graham Greene described epilepsy alongside cancer and leprosy as the condition most feared by the British public (Greene 2011). This would not have been helped by its portrayal in theatres. The inclusion of deaths at the hands of a character during a seizure would have stoked fear and unease within audiences reducing public trust and understanding of people with epilepsy. This was at a time when people with epilepsy were already widely ostracized to the point where marriages could legally be annulled due to a diagnosis of epilepsy.

A change in the portrayal of epilepsy has only started to occur in the last forty or so years. A more natural portrayal with epilepsy as a key part of a protagonist's journey. Night Mother by Marsha Norman is a Pulitzer Prize winning play that premiered in 1982. The play revolves around the character of Jessie and her mother. On the night the play is set, Jessie has decided to end her life and the play covers her final couple of hours. Jessie has been worn down by her family and her life in small town America. To her, suicide is the only way to actually take control of her life. In the play, Jessie is described as having had seizures since childhood. It is also mentioned that her father suffered from seizures as well. While her epilepsy is just one of the factors that has led her to this point in her life, the importance of the seizures in her decision is made clear.

JESSIE - This is how I have my say. This is how I say what I thought about it all and I say No. To Dawson and Loretta and the Red Chinese and epilepsy and Ricky and Cecil and you. And me. And hope. I say No! (Norman 1983, 49)

The play also provides an understanding of public opinions on epilepsy at the time and the shame that existed over the condition. For example, her mother tried to hide Jessie's seizures for as long as possible for fear of public embarrassment.

JESSIE - But you didn't tell anybody.

MAMA - It was none of their business.

JESSIE - You were ashamed.

MAMA - I didn't want anybody to know. Least of all you. (Norman 1983, 46)

It is worth noting that the person who is most ashamed of Jessie's epilepsy is not Jessie but her mother who worries about how society will respond to someone with epilepsy.

MAMA - Make you feel like a freak, is that what I should have done? (Norman 1983,

46) 
But Jessie does not feel like a freak because of her epilepsy. Jessie shows herself to be more pragmatic than her mother.

JESSIE - It's just a sickness, not a curse. Epilepsy doesn't mean anything. It just is. (Norman 1983, 47)

It is Mama who is ashamed of her daughter's epilepsy. The problem with the diagnosis and the fear of being stigmatised and rejected by society lies with her. A failing that has had a detrimental effect on Jessie.

The play is an exploration of control and the aspects of our life that we are really able to influence. For Jessie, epilepsy is one uncontrollable aspect of her life. Like many people living with epilepsy, she has had to live her life knowing that she has no control over when another seizure may take place. Medication and lifestyle choices may help to reduce seizures but aren't a cure. The fear and worry of a seizure is always present. She is only able to truly take control of her life once she accepts the uncontrollable nature of life. Part of the tragedy is that it is the mother's response to her daughter having epilepsy and her fear about what other people would say, that may have helped set Jessie on the path to her decision. Jessie is level headed and rational and the decision to end her life has been taken over time. The audience are confronted with the idea that a seemingly sane person might choose to end their own life, a concept that might be inconceivable to most people. It challenges the viewer to confront how societal attitudes may influence individuals. Perhaps if the society they lived in was more accepting of people with disabilities then Jessie's life would have panned out differently.

\section{$21^{\text {st }}$ Century Plays}

Three Thousand Seizures by American playwright Christina Quintana, is a modern play written specifically about epilepsy. It follows the lead character Petra as she undergoes resective brain surgery to treat her epilepsy and through her recovery. At times during the play, Petra has seizures, but the play notes make clear these should not be physicalized as 'seizures'. Instead, they are depicted on stage through the language and physicality of three characters referred to as The Seizures. During a seizure, Petra also interacts with Michael IV of Paphlagonia, a real person who rose from being a peasant to become Emperor of Byzantine whilst suffering from epilepsy. These interactions allow Petra to talk about her epilepsy in ways that she is incapable of with her friends and family.

The play tries to portray an accurate picture of the medical process as well as the reaction of family and friends to her condition. Quintana explores what it means to have epilepsy and how that may affect someone's sense of identity. At the beginning of the play Petra accepts that having epilepsy is part of who she is and that it makes her different.

PETRA: Right, but they're my seizures. They've always been there. I can't even imagine what my life would look like without them... I am me because of them. (Quintana 2017, 5)

However, she is aware that her seizures have affected her life and how other people see her.

PETRA: I was always that girl with the Seizures. It was my mark. A mark, but my mark all the same... (Quintana 2017, 53)

Altogether, it portrays a pragmatic character who has come to terms with her disability and tried not to let it control her life, helping to build a successful business. A unique aspect of Three Thousand Seizures, is the provision of voices to Petra's seizures. Quintana stresses this connection between 
Petra and her condition in the depiction of her epilepsy as three characters called the seizures who speak almost as one.

ONE: You've been unable to find your words.

TWO: We're holding onto them for you.

ALL THREE: We've got them all. (Quintana 2017, 11)

However, providing the epilepsy with an alternative voice has the downside of suggesting epilepsy as a foreign entity such as a virus or bacteria. Something that can be vanquished. It almost links back to the ancient beliefs that epilepsy was due to some sort of possession and not a physiological reaction to errors from the brain's own neurons. This conflict continues with the character of Michael IV of Paphlagonia, who first appears to Petra during a seizure and continues to reappear after the surgery. It is not until Petra has come to the necessary acceptance to move forward with her life that he disappears. This depiction of Petra's mind still providing a sense of being during a seizure is at odds with our understanding. People lose awareness during seizures, not knowing what has happened once the seizure has ended. While the logic of his appearance is questionable and must be accepted as dramatic licence, what his appearance does is provide Petra with a sounding board to openly discuss her epilepsy and various relationships.

Three Thousand Seizures was written specifically to explore epilepsy. Petra's epilepsy has not been added as a character trait or merely used to help move the plot along. The play is intended to raise awareness of epilepsy, its impact on people as well as the lengths people are required to go to for treatments. It also confronts the emotions experienced by those affected by epilepsy and how they may struggle. Pascal's fear that Petra is altered by the surgery and his inability to confront the emotions involved in recovering from such major surgery are not justified but portrayed as a legitimate human response to an emotive situation.

Another recent play, 2401 Objects explores the life and historical impact of Henry Molaison. More famously known as Patient HM, Henry is one of the most well-known neurological cases in the world. In 1953, Henry underwent experimental brain surgery to try and treat his epilepsy. However, following the surgery, he was left with amnesia meaning that he was unable to create any new memories. As a result he became a case study for many neuroscientists keen to understand how memories form in the brain. The creation of Patient HM has meant that the person Henry Molaison has, to some degrees, been forgotten about. This play attempts to redress this situation, honestly depicting the strain epilepsy can have on families and the risks people are willing to take in a search of a cure.

Henry lived with his parents who acted as his carers. At the start of the play, his parents reveal the strain that his epilepsy places upon them, highlighting the impact the condition has not just on the individual but those people who care for them.

MOTHER: I want to go away. Sometimes I feel if I don't get away I'll break, something inside will be pulled so tightly it will snap and I'll break, shut down. But I won't. We won't. (Barker et al. 2011, 48)

It also confronts the impact that epilepsy can potentially have on a person's opportunities and the frustrations inherent in a life restricted by illness. 
FATHER: I'm saying don't you ever think about who he was supposed to be? (Barker et al. 2011, 49)

The life that Henry might have without epilepsy is also raised through a potential romance with the girl next door. It is the strain and missed potential that pushes Henry's parents, who only want the best for their son, towards the high-risk surgery performed by Dr William Scoville. In the play, Dr Scoville is described as 'flamboyant, boisterous even...' (Barker et al. 2011, 43). While these may not necessarily be the most reassuring characteristics for a surgeon, the play suggests that it is these characteristics that give him the confidence required to attempt such risky surgery. However, it is left up to the audience to decide for themselves whether Dr Scoville was a reckless surgeon or a pioneer trying to advance neurosurgical techniques.

2401 Objects was written and developed by Analogue Theatre Company in collaboration with various consultants. The depiction of Henry's life is honest and simple. This collaborative approach to theatre development ensures accuracy to the science used in the piece while promoting public engagement with scientific research. While research is an important aspect in the writing of any play, this active collaboration with specialists can provide a reassuring authenticity to a piece.

The impact of Henry Molaison on neuroscience is shown by the number of plays to have explored his life. Nick Paine's play, Incognito, which explores aspects of neuroscience more widely includes Henry as a character, focussing on Henry after his surgery. However, there are two brief incidents where Henry is portrayed having a seizure.

Henry goes blank. Beat.

MARGARET: Henry?

Henry is mentally absent for a few seconds more.

MARGARET: Henry - Henry.

HENRY: Yes.

MARGARET: You disappeared. (Paine 2014, 44)

This first incident represents an absence seizure, a kind of generalized seizure that are characterized by a brief loss and return of consciousness. The second incident occurs shortly afterwards and relates to a more severe tonic clonic seizure. Absence seizures can be followed by tonic clonic seizures as abnormal brain activity begins and then spreads across the brain.

Henry has a seizure, a 'grand mal': a stiffening of the limbs followed by rhythmic convulsions.

MARGARET: Henry - Henry - Henry!

HENRY: (suddenly 'back to normal') Hello my love, where have you been? (Paine 2014, 46)

The description of the speed of recovery from the grand mal seizure as sudden is unrealistic, although the postictal confusion shown by Henry is typical. Ultimately, how the seizure is seen by the audience will be down to the actor and director. But limited by the constraints of needing to keep the play moving on, the scene is likely to only reveal a fleeting suggestion of the condition that started the journey to Patient HM.

Making for the Light by Operating Theatre is another play written as a collaboration between scientists and artists. Developed in response to research being led by Newcastle University into a new therapy for epilepsy, it was written following numerous interviews and discussions with project 
members as well as members of the epilepsy community. The play explores the impact that epilepsy can have on lives, following the character of Ellen up to the decision to undergo surgery for a new therapy. While not shying away from the impact of the condition, the piece aims to highlight the experience of living with epilepsy.

... and as she was trying to explain from her foetal position that that wouldn't be necessary, that her head was already beginning to clear her boss literally stepped over her to get to his office. (Elliott 2018, 10)

Throughout the piece, mention is made of historical people who are known or believed to have had epilepsy including Vincent van Gogh, Emily Dickinson, Fyodor Dostoyevsky and the poet Edward Lear.

Ellen began to take an interest in other artists who, like her, experienced the heart stopping and brain twisting incidents that Edward Lear resolutely refused to mention in his diaries. (Elliott 2018, 10-11)

Inspired by science, real-life testimony and historical facts, the piece is told through two characters in Ellen's head during a seizure. In that respect it has similarities to Three Thousand Seizures but the voices are very much a subconscious part of her as opposed to a vocalisation of the seizure. Meanwhile, the references to historical figures with epilepsy provide a connection for audiences, reaffirming the realities behind the play.

There are a number of other examples of collaborative works that explore living with epilepsy. All of which are by and large smaller theatre companies. However, this can often allow companies to be more experimental. Beyond My Control by Exeter Northcott Theatre in association with the University of Exeter is described as "an interactive modelling performance about epilepsy, excitability and all things neurological" (Exeter Northcott Theatre, n.d.). Beyond My Control takes a completely different stance to portray epilepsy, interpreting the neurological basis of the condition, the connections within the brain and how it can result in seizures. Using improvisation techniques, it reflects the uncertain nature of epilepsy, while also helping to portray complicated scientific and mathematical concepts. Alongside the improvisational modelling, the piece also involves individual testimonies from people living with epilepsy which help to highlight the reality behind the show.

There are also a number of solo shows written and performed by people with epilepsy such as Jack Cray: The Fittest Guy on the Street by Jack Cray and Can You See into a Black Hole? by Thomas Ryalls. Simple, honest and open portrayals of their experience of living with epilepsy. A more extreme theatre production that was intended to provoke reactions was Involuntary Dances by Rita Marcalo. During the performance Marcalo, a dancer who has epilepsy, attempted to induce a seizure on stage. This idea of not just depicting but actively having a seizure, was explained as an attempt to educate people about epilepsy. By doing so, Marcalo was looking to bring seizures, which normally occurred in private, into the public realm (Marcalo 2012, 59). Criticism from epilepsy charities helped to bring the project to the attention of the media (Guardian, November 20, 2009).

\section{Summary}

It has often been the so called fringe shows that have led the way in influencing theatre trends. Disability cannot just be used as a simple artistic device to make a story more exciting and people are now more aware that how disability is portrayed on stage has implications. Many of today's artists are attempting to take control of the narrative surrounding epilepsy and to show it as it really is. In 
this manner, the theatre appears to be ahead of film and television who continue to link seizures to horror and the paranormal (Baxendale 2016, 273).

But it has taken a long time for theatre to embrace these realistic portrayals of epilepsy. It would be all too easy to sink back into sensationalism and stereotypes. Theatres need to take responsibility and not commission or put on shows involving outdated and simplistic characters. The only concession being if the aim is to show to audiences why this portrayal is wrong, whether directly in a show or via supplementary material. Theatre has the power to change perceptions of disability (Dupuis et al. 2016, 1050). Consequently it should be supported to ensure that it changes perceptions in the right way.

Spend any time with someone with epilepsy and you will discover their personal story is dramatic, emotional and engaging. All essential characteristics for a successful play. It should be possible to put these stories or inspired stories on the stage to widespread success. This has already happened for a number of different neurological conditions that have broken through into the mainstream. For example The Curious Incident of the Dog in the Night, adapted by Simon Stephens from the book by Mark Haddon, which portrays the world of autism. Also The Father by Florian Zeller which shows the impact of living with dementia and which has been adapted into a movie starring Anthony Hopkins. With the success of these plays, it is hopeful that a play with a similar portrayal of epilepsy will be able to come through and promote awareness in a similar way.

\section{$\underline{\text { References }}$}

Aeschylus, 2007. The Oresteia. Edited and translated by Marianne McDonald and J. Michael Watson. London: Nick Hern Books Limited. Drama Online.

Barker, Hannah, Lewis Hetherington and Liam Jarvis. 2011. 2401 Objects. Oberon Modern Plays. Baxendale, Sallie. 2016. "Epilepsy on the silver screen in the $21^{\text {st }}$ century." Epilepsy \& Behavior, 57 : 270-4. https://doi.org/10.1016/j.yebeh.2015.12.044.

Betts, Tim., \& Betts, Hannah. 1998. “A note on a phrase in Shakespeare's play King Lear: 'A plague upon your epileptic visage'." Seizure 7 (5): 407-9. https://doi.org/10.1016/S10591311(05)80011-1.

Cazan, Roxana. 2014. ““What Shall We Hear of This”: Understanding Judgment, Epilepsy in William Shakespeare's Tragedies.” Neophilogus, 98(3), 503-16.

Dupuis, Sherry L, Gail J. Mitchell, Christine M. Jonas-Simpson, Colleen P. Whyte, Jennifer L. Gillies, and Jennifer D. Carson. 2016. "Igniting Transformative Change in Dementia Care Through Research-based Drama.” The Gerontologist 56 (6): 1042-52. https://doi.org/10.1093/geront/gnv062.

Elliott, Alex, and Operating Theatre. 2018. Making for the Light. Accessed May 22, 2020. http://www.cando.ac.uk/illuminatingtheself/operatingtheatre/.

Euripides. 1999. Trojan Women. Iphigenia among the Taurians. Ion. Edited and translated by David Kovacs. Cambridge, MA: Harvard University Press. Loeb Classical Library.

Euripides. 1997. Herakles. Translated by Kenneth McLeish. London: Bloomsbury Publishing. Drama Online.

Exeter Northcott Theatre. "Beyond My Control." Accessed May 11, 2020. https://www.exeternorthcott.co.uk/archived-events/beyond-my-control/. 
Galassi, Francesco M. and Hutan Ashrafian. 2015. "Has the diagnosis of a stroke been overlooking in the symptoms of Julius Caesar." Neurol Sci 36 (8): 1521-22. https://doi.org/10.1007/s10072-015-2191-4.

Greene, Graham. 1971. A Sort of Life. Random House.

Hippocrates. N.d. On the Sacred Disease.

Holmes, Emily, Siobhan Bourke and Catrin Plumpton. 2019. "Attitudes towards epilepsy in the UK population: Results from a 2018 national survey." Seizure 65: 12-19. https://doi.org/10.1016/j.seizure.2018.12.012.

Kerson, Toba S, Jennie F. Kerson, and Lawrence A. Kerson. 2000. "She can have a seizure maybe; then we can watch: The portrayal of epilepsy in film." Social Work in Health Care 30 (3): 95110. https://doi.org/10.1300/J010v30n03_06.

Magiorkinis, Emmanouil, Kalliopi Sidiropoulou, and Aristidis Diamantis. 2010. "Hallmarks in the history of epilepsy: Epilepsy in antiquity." Epilepsy \& Behavior 17 (1): 103-8. https://doi.org/10.1016/j.yebeh.2009.10.023.

Magiorkinis, Emmanouil, Aristidis Diamantis, Kalliopi Sidiropoulou, and Christos Panteliadis. 2014. "Highlights in the History of Epilepsy: The Last 200 Years." Epilepsy Research and Treatment. 2014. https://doi.org/10.1155/2014/582039.

Marcalo, Rita. 2012. "Involuntary dances." Research Ethics 8 (1): 57-59. https://doi.org/10.1177/1747016112437686.

Marsh, Laura and Gregory L. Krauss. 2000. "Aggression and violence in patients with epilepsy." Epilepsy \& Behavior 1 (3): 160-8. https://doi.org/10.1006/ebeh.2000.0061.

Norman, Marsha. 1983. Night Mother. London: Faber and Faber.

Paine, Nick. 2014. Incognito. London: Faber \& Faber.

Quintana, Christina. 2017. Three Thousand Seizures. Abrams Artists Agency.

Shakespeare, William. Julius Caesar. The "Pocket Falstaff" Edition of Shakespeare's Complete Works. London. Sands \& Company.

Shakespeare, William. Othello. The "Pocket Falstaff" Edition of Shakespeare's Complete Works. London. Sands \& Company.

Shakespeare, William. King Lear. The "Pocket Falstaff” Edition of Shakespeare's Complete Works. London. Sands \& Company.

Stephens, Simon, and Mark Haddon. 2012. The Curious Incident of the Dog in the Night-time. London: Methuen Drama. Drama Online.

Trimble, Michael, and Dale C. Hesdorffer. 2016. "Representations of epilepsy on the stage: from the Greeks to the $20^{\text {th }}$ century." Epilepsy \& Behavior 57: 238-42. https://doi.org/10.1016/j.yebeh.2016.01.008.

Wells, Stanley. 2015. "Othello." In The Shakespeare Book, edited by Stanley Wells, 240-249. London: Dorling Kindersley Limited.

Zeller, Florian. 2015. The Father. Translated by Christopher Hampton. Faber and Faber. Drama Online. 